\title{
Systemy do rejestracji późnych potencjałów korowych
}

\section{Study system of late cortical responses}

\section{Małgorzata Ganc}

\author{
Instytut Fizjologii i Patologii Słuchu, Światowe Centrum Słuchu, Zakład Audiologii Eksperymentalnej, \\ Warszawa/Kajetany
}

Adres autora: Małgorzata Ganc, Światowe Centrum Słuchu, Zakład Audiologii Eksperymentalnej, ul. Mokra 17, Kajetany, 05-830 Nadarzyn, e-mail: m.ganc@ifps.org.pl

\begin{abstract}
Streszczenie
Potencjały wywołane definiowane są jako odpowiedzi bioelektryczne struktur mózgu na określony bodziec. Późne potencjały korowe należą do grupy odpowiedzi wywołanych, których miejscem generacji jest przede wszystkim kora mózgu. Zyskują one coraz szersze zastosowanie w diagnostyce różnych schorzeń. Na rynku pojawiają się coraz bardziej skomplikowane systemy umożliwiające wywoływanie i rejestrację odpowiedzi z wyższych pięter drogi słuchowej, wzrokowej i czuciowo-ruchowej.
\end{abstract}

Celem pracy było przedstawienie i ocena dostępnych systemów badawczych i urządzeń do rejestracji późnych potencjałów korowych. Analizy urządzeń dokonano na podstawie informacji dostępnych na stronach internetowych producentów urządzeń do badań późnych potencjałów korowych oraz informacji otrzymanych bezpośrednio od przedstawicieli handlowych w Polsce.

Słowa kluczowe: późne odpowiedzi korowe • potencjały poznawcze • ERP

\begin{abstract}
Evoked potentials are defined as bioelectric responses of brain structures to particular stimuli triggering them. Late cortical responses are increasingly used in diagnostics of various diseases. More and more innovative systems are designed to register late cortical responses. There are many complex systems available commercially that enable both evoking and recording responses from the superior levels of auditory, visual and sensorimotor nervous pathways.
\end{abstract}

The aim of this study was to present and assess available study systems and tools for investigating late cortical responses. The evaluation of tools was conducted on the basis of information available on the websites of manufacturers producing devices for the analysis of late cortical responses and information obtained directly from sales representatives in Poland.

Key words: late cortical responses • cognitive potentials • ERP

\section{Wprowadzenie}

Potencjały wywołane (ang. evoked potentials, EP) to swoiste bioelektryczne odpowiedzi poszczególnych struktur mózgu na bodźce o różnej modalności. Potencjały wywołane można uzyskać w odpowiedzi na bodźce słuchowe, wzrokowe bądź dotykowe. Potencjały korowe należą do grupy odpowiedzi wywołanych, których miejscem generacji są przede wszystkim ośrodki podkorowe i kora mózgu o czasie utajenia (latencji) w zakresie 50-1000 ms [1]. Potencjały te dzielimy na dwie grupy: potencjały egzogenne, zwane również potencjałami sensorycznymi, których powstanie związane jest $\mathrm{z}$ bodźcem, oraz potencjały endogenne, nazywane poznawczymi, związane ze zdarzeniem (ang. event related potential, ERP).

Do odpowiedzi egzogennych zaliczamy fale P1, N1, P2 oraz falę niezgodności MMM, choć odnotowuje się, że na parametry tej ostatniej ma wpływ uwaga osoby badanej. Do odpowiedzi endogennych należą załamki N2, P300, N400 i P600 [1]. Parametry potencjałów egzogennych są ściśle zależne od parametrów fizycznych bodźca wywołującego, natomiast potencjały endogenne są miarą procesów analizy informacji określonych struktur mózgu na nieoczekiwaną zmianę parametrów bodźca zachodzących na wyższych piętrach dróg sensorycznych osoby badanej. Poszczególne załamki generowane są w drogach transmitujących informację ze wzgórza do kory, ale przede wszystkim odzwierciedlają procesy przebiegające w samej korze słuchowej, wzrokowej, somatosensorycznej oraz w strukturach i sieciach mózgowych, związanych np. z poznawczym czy emocjonalnym przetwarzaniem informacji przez badanego [2-4]. Na parametry tych odpowiedzi (latencję, amplitudę) oraz morfologię zapisu wpływ mają procesy czy zmienne związane z przetwarzaniem językowym. Potwierdziły to wyniki prac specjalistów zajmujących się 
diagnostyką pacjentów z problemami językowymi za pomocą potencjałów korowych [5]. Poszczególne składowe odpowiedzi endogennych, takie jak fala P300 czy N400, można wykorzystywać w ocenie krótkotrwałej pamięci słuchowej [6], procesów kategoryzacji bodźców czy procesów przetwarzania semantycznego i syntaktycznego, które zależą od uwagi $[2,5]$. Uważa się bowiem, że składowe te są bioelektrycznym markerem wymienionych powyżej procesów. Potencjały endogenne mogą być zatem wykorzystywane $\mathrm{w}$ diagnostyce pacjentów $\mathrm{z}$ różnego rodzaju zaburzeniami procesów poznawczych czy też procesów związanych $\mathrm{z}$ mową [2].

Późne potencjały korowe znajdują również zastosowanie w diagnostyce i ocenie funkcjonowania „wyższych” procesów mózgowych u pacjentów np. z problemami neurologicznymi czy psychicznymi $[7,8]$. Potencjały endogenne są też coraz częściej wykorzystywane w audiologii, w diagnostyce osób jąkających się [9], w badaniach pacjentów z wszczepionym implantem ślimakowym [10,11], u osób z szumami usznymi [12]. Diagnostyka z wykorzystaniem potencjałów endogennych obejmuje także osoby ze specyficznymi zaburzeniami językowymi (ang. specific language impairment, SLI) $[13,14]$, zespołem nadpobudliwości psychoruchowej (ang. attention deficit hyperactivity disorder, ADHD) $[15,16]$ czy osoby z centralnymi zaburzeniami słuchu [17]. Potencjały endogenne wykonywane są również u pacjentów w stanie śpiączki, w stanach wegetatywnych i u osób nieprzytomnych w celu diagnozy i oceny rokowań dotyczących powrotu do zdrowia [18,19]. Ponadto potencjały korowe stanowią narzędzie do ewaluacji efektów prowadzonych treningów i terapii, z którego korzystają neuropsycholodzy i terapeuci [20].

Duże możliwości wykorzystania systemów do rejestracji odpowiedzi średniolatencyjnych i korowych powodują, że w wersjach komercyjnych tworzone są coraz nowocześniejsze systemy do wywoływania i rejestrowania tych potencjałów. Dostępne urządzenia można najogólniej podzielić na urządzenia diagnostyczno-kliniczne oraz naukowe. Urządzenia diagnostyczne to najczęściej jedno- lub dwukanałowe aparaty służące do wykonania szybkich rejestracji, oceniających przetwarzanie informacji na poziomie podkorowym i korowym. Natomiast urządzenia kliniczne to wielokanałowe systemy pozwalające na rejestrację odpowiedzi wywołanych za pomocą wielu elektrod umieszczonych na głowie pacjenta. Systemy te wykorzystywane sa z uwagi na złożone procesy analizy uzyskanej odpowiedzi - w pracowniach naukowych. W systemach diagnostycznych analiza zarejestrowanych odpowiedzi wykonywana jest automatycznie bezpośrednio po przeprowadzeniu badania, a nawet $\mathrm{w}$ trakcie jego trwania. Systemy naukowe z reguły pozwalają wyłącznie zarejestrować sygnał czynności bioelektrycznej mózgu EEG (elektroencefalografia), a wyniki uzyskuje się dopiero po odpowiednim opracowaniu sygnału. Systemy naukowe wymagają zaawansowanej obróbki zarejestrowanego sygnału, polegającej na usunięciu artefaktów, przeprowadzeniu analiz Fouriera (ang. fast Fourier transform, FFT) czy wykonaniu analizy składowych niezależnych (ang. independent component analysis, ICA).

Oprócz wykonywania samych rejestracji potencjałów wywołanych systemy diagnostyczno-kliniczne umożliwiają również rejestrowanie innych grup potencjałów, takich jak potencjały wywołane pnia mózgu (ang. auditory brainstem response, $\mathrm{ABR}$ ) czy słuchowe potencjały wywołane stanu ustalonego (ang. auditory steady-state responses, ASSR).

\section{Cel pracy}

W pracy dokonano analizy funkcjonalności oraz przydatności systemów do rejestracji i analizy słuchowych późnych odpowiedzi korowych pod kątem wykorzystania ich w pracowni diagnostyczno-klinicznej oraz w badaniach naukowych. Oceniono systemy oferowane przez firmy: Neurosoft, Otometrics, Natus, Nihon Kohden, Mitsar, Cadwell, Eemagine Medical Imaging Solutions $\mathrm{GmbH}$, Compumedics oraz Electrical Geodesics (EGI).

\section{Metodyka i materiał analiz}

Analizy urządzeń dokonano na podstawie informacji dostępnych na stronach internetowych producentów urządzeń oraz informacji otrzymanych bezpośrednio od przedstawicieli handlowych w Polsce.

Do systemów diagnostyczno-klinicznych należą: Chart EP 200 firmy GN Otometrics, Neuro-Audio firmy Neurosoft czy Navigator Pro AEP skonstruowany przez BIO-logic. Do celów naukowych przeznaczone są aparaty umożliwiające rejestrację czynności bioelektrycznej podczas zadania, rejestrowane z powierzchni czaszki z wielu odprowadzeń. Do takich systemów zaliczyć należy 6- lub 12-kanałowy MEB-2300 K z firmy Nihon Kohden, 19-kanałowy Mitsar, 28-kanałowy Neuron-Spectrum-4/EPM znajdujący się w ofercie firmy Neurosoft, 64-kanałowy SynAmps RT produkowany przez Compumedics czy rozbudowany nawet do 256 kanałów sprzęt GES 400 Series polecany przez Electrical Geodesics (EGI). Zainteresowanie powinien wzbudzić przenośny aparat Eego sport z firmy Eemagine Medical Imaging Solutions GmbH, który może być wykorzystany do rejestracji późnych potencjałów korowych na przykład u sportowców, studentów i pacjentów w trakcie wykonywania różnych zadań w warunkach zbliżonych do naturalnych.

\section{Przegląd wybranych urządzeń do wykonywania badań diagnostyczno-klinicznych}

W pracowniach zajmujących się prowadzeniem szerokiej diagnostyki pod kątem występowania zaburzeń przetwarzania słuchowego oczekiwane jest zastosowanie systemów i urządzeń cechujących się prostą i intuicyjną obsługą, standardowymi protokołami badań oraz nieskomplikowaną analizą uzyskanych rejestracji. Rejestracje powinny być możliwe do wykonania za pomocą minimalnej liczby elektrod (mała liczba kanałów), przy zachowaniu bardzo dużej czułości i specyficzności wykonywanych badań.

Do takich urządzeń, prostych w obsłudze i niewymagających zaawansowanego opracowywania rejestrowanych sygnałów, należą systemy produkowane przez firmę Neurosoft. W asortymencie firma ta posiada następujące systemy: 2-kanałowy Neuro-Audio, 4- bądź 8-kanałowy Neuro-MEP (rycina 1) oraz 28-kanałowy Neuron-Spectrum-4/EPM, który przeznaczony jest zarówno do rejestracji czynności bioelektrycznej mózgu, jak i do 4-kanałowych badań ERP. 


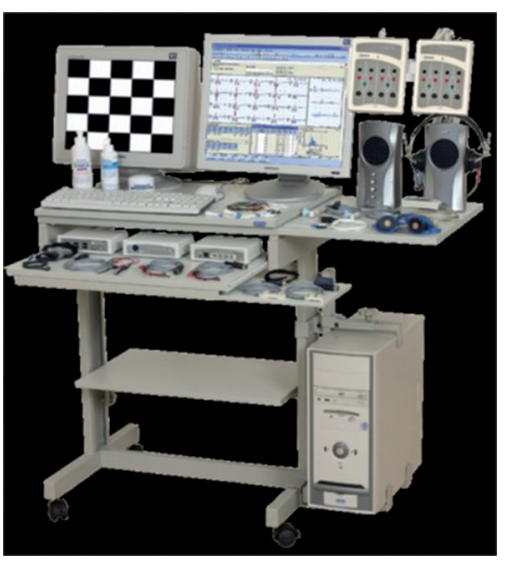

Rycina 1. System Neuro-MEP

Figure 1. Neuro-MEP system

Najciekawszym systemem diagnostycznym w ofercie firmy Neurosoft jest aparat Neuro-Audio, który umożliwia przeprowadzanie bardzo szerokiej diagnostyki audiologicznej. System posiada wbudowany audiometr, pozwalający wykonywać badania audiometryczne do $16 \mathrm{kHz}$ zarówno dla przewodnictwa powietrznego, jak i kostnego, moduł do wykonywania otoemisji akustycznych, otoemisji spontanicznych (ang. spontaneous otoacoustic emissions, SOAE) oraz produktów zniekształceń nieliniowych ślimaka (ang. distortion product otoacoustic emissions, DPOAE). Daje również możliwość wykonywania elektrokochleografii (EcoG), słuchowych potencjałów wywołanych, takich jak ABR, potencjałów średniolatencyjnych (ang. middle latency responses, MLR) i długolatencyjnych (ang. late latency response, LLR), słuchowych potencjałów stanu ustalonego (ang. auditory steady-state response, ASSR), miogennych przedsionkowych potencjałów wywołanych (ang. vestibular evoked myogenic potential, VEMP), a także potencjałów związanych ze zdarzeniem ERP. Pozwala też na rejestrację potencjałów późnolatencyjnych - komponentu P300 oraz fali niezgodności (ang. mismatch negativity, MMN). Urządzenie, umożliwiając wykonanie wielu różnych badań audiologicznych, cechuje się jednocześnie niewielkimi rozmiarami oraz ma wersję przenośną, współpracując z komputerem typu notebook. Posiada intuicyjny i wygodny w użytkowaniu interfejs, a wyniki badań dokumentowane są za pomocą konfigurowalnych raportów. Rejestracje odpowiedzi wywołanych wykonywane są poprzez 16-bitowy przetwornik analogowo-cyfrowy z częstością próbkowania od 0,2 do $80 \mathrm{kHz}$.

System Neuro-MEP w porównaniu z Neuro-Audio jest urządzeniem przeznaczonym do badań EMG, ENG i PW, rozbudowanym o możliwość przeprowadzania badań wzrokowych potencjałów wywołanych (ang. visual evoked potential, VEP), za pomocą prezentacji dowolnych wzorców poprzez okulary bądź na monitorze zewnętrznym. Rejestrację fali P300, CNV (ang. contingent negative variation) i MMN uzyskuje się w wyniku stymulacji akustycznej przez słuchawki.

Urządzenie Chart EP 200 to prosty w obsłudze aparat umożliwiający zarówno jedno-, jak i dwukanałowe rejestracje potencjałów korowych (fali P300 i MMN). Pozwala również na wykonanie badania ABR, MLR, LLR, ASSR, VEMP oraz ECoG (ang. electrocochleography).

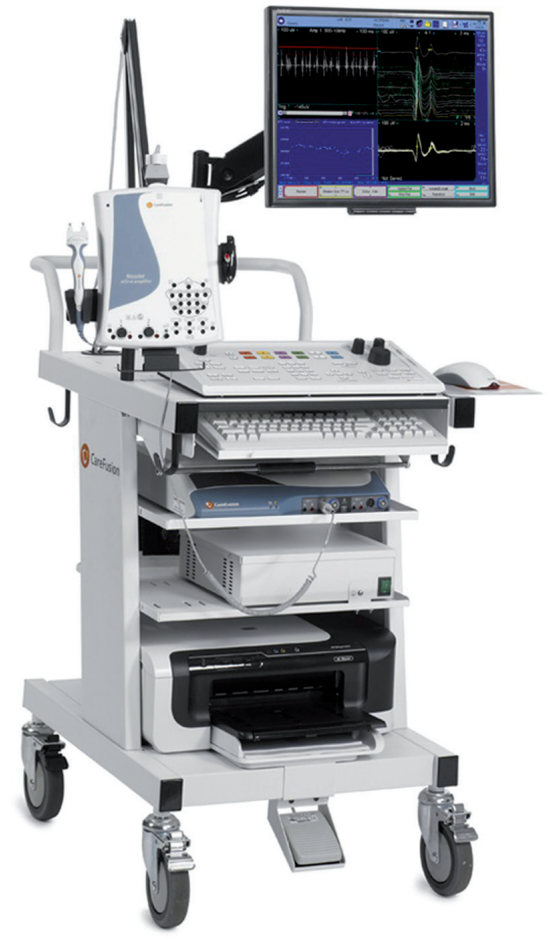

Rycina 2. System Nicolet Viking EDX Figure 2. Nicolet Viking EDX system

Aparat posiada 16-bitowy przetwornik analogowo-cyfrowy, a bodźce mogą być prezentowane $\mathrm{z}$ częstością od 0,2 do $180 \mathrm{~Hz}$. Dużą zaletą systemu jest możliwość dowolnej konfiguracji prezentowanych bodźców stymulujących przy rejestracji każdej z dostępnych grup potencjałów. Prosty i intuicyjny interfejs umożliwia dokonanie niezbędnych $\mathrm{w}$ badaniu diagnostycznym operacji na zarejestrowanych sygnałach - sumowanie i odejmowanie odpowiedzi, naniesienie znaczników, pomiar latencji i amplitud poszczególnych fal odpowiedzi. Wygenerowany w formie raportu wynik badania umożliwia ocenę i interpretację cech badanych odpowiedzi wywołanych w gabinecie diagnostycznym.

Kolejnym urządzeniem przeznaczonym dla pracowni diagnostyczno-klinicznych jest Nicolet Viking EDX (rycina 2) pozwalający na rejestrację odpowiedzi wywołanych przy wykorzystaniu od 2 do nawet 8 kanałów. System oferowany jest w dwóch wersjach: stacjonarnej oraz przenośnej. Posiada on 24-bitowy przetwornik analogowo-cyfrowy. Oprócz rejestracji późnych potencjałów korowych (fali P300 oraz ujemnej fali oczekiwania CNV) urządzenie umożliwia wykonywanie rejestracji EMG, SEP (ang. somatosensory evoked potentials), słuchowych oraz wzrokowych potencjałów wywołanych. Program medyczny „Viking EP Plus”, w który wyposażony jest system, zawiera wszystkie rutynowe schematy badawcze do wywoływania i rejestracji SEP, AEP i VEP. Posiada także możliwość tworzenia własnych paradygmatów badań, w tym możliwość rejestracji z 8 kanałów jednocześnie oraz niezależne ustawienie czułości i filtrów wzmacniaczy w każdym z kanałów. Możliwe jest również stworzenie do 100 niezależnych protokołów, dla trzech modalności. 


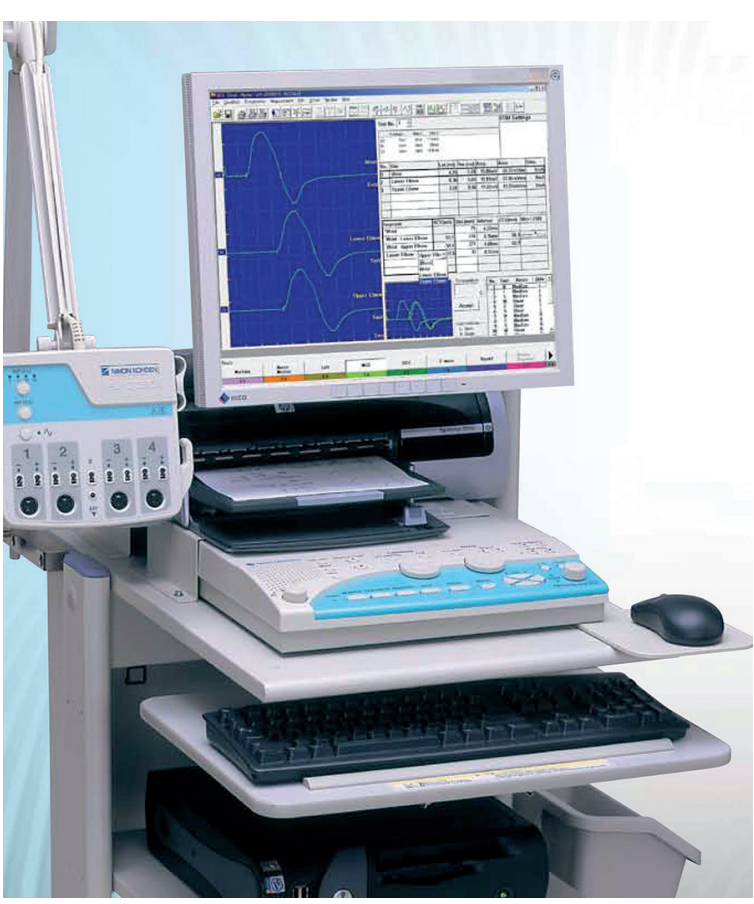

Rycina 3. System MEB-9400

Figure 3. MEB-9400 system

System umożliwia wykonanie korekcji linii bazowej (ang. baseline correction), posiada funkcję wygładzania otrzymywanych krzywych w czasie i po wykonaniu rejestracji (ang. smoothing) oraz ich odejmowania, dodawania, odwracania i nakładania na siebie. Na każdej krzywej, za pomocą nawet 8 markerów, można zaznaczyć poszczególne fale występujące w odpowiedzi potencjałów wywołanych. Wynik w formie raportu zawiera tabelę wartości latencji i amplitudy odpowiedzi.

System wyposażony jest także w moduł umożliwiający tworzenie własnych sekwencji bodźców do stymulacji akustycznych, np. różnego rodzaju trzasków czy tonów o różnych obwiedniach: liniowej, Gausa, Hanninga czy Blackmana, jak również bodźców wzrokowych. Potencjały wzrokowe mogą być wywoływane za pomocą specjalnej przystawki okularowej lub poprzez stymulację prowadzoną z monitora zewnętrznego dla bodźców takich jak np. pionowe czy poziome pasy, szachownice różnej wielkości, prezentowane na całym ekranie, połowie, ćwiartce lub tylko w części środkowej ekranu.

Kolejnym urządzeniem do rejestracji odpowiedzi korowych jest Navigator Pro opracowany przez specjalistów z firmy Biologic. Urządzenie poprzez 16-bitowy przetwornik analogowo-cyfrowy o częstości próbkowania $48 \mathrm{kHz}$ pozwala na wykonanie również rejestracji ABR, MLR, ASSR, eABR i EcOG.

Odpowiedzi korowe uzyskuje się na podstawie jedno- lub dwukanałowej rejestracji. System ma wbudowane standardowe protokoły pomiarowe, jak również pozwala na ich dowolne modyfikowanie. Umożliwia ponadto zaawansowaną obróbkę zarejestrowanych odpowiedzi: sumowanie, odejmowanie, uśrednianie i odwracanie zarejestrowanych krzywych, korelacje czy obliczanie pola powierzchni pod krzywą potencjału.

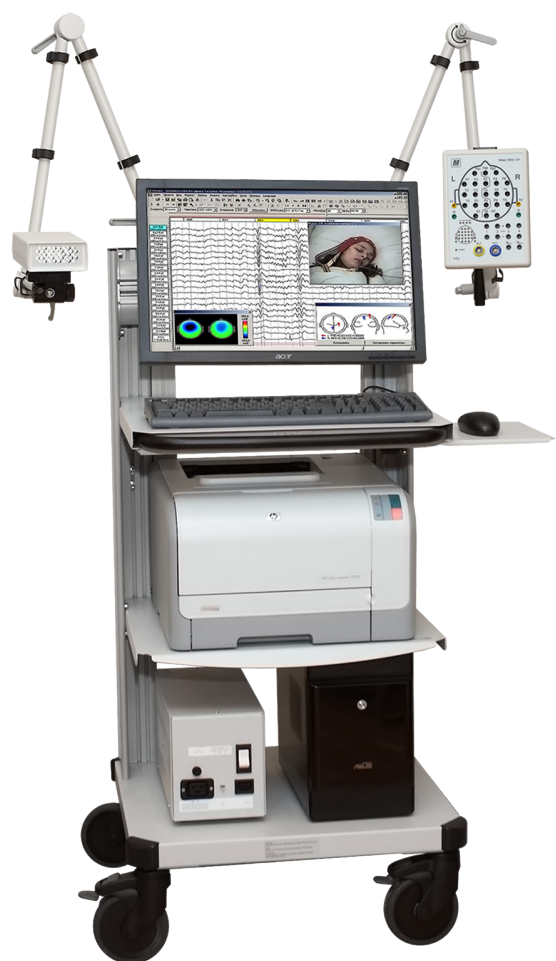

Rycina 4. System Mitsar

Figure 4. Mitsar system

Następnymi systemami do rejestracji późnych potencjałów korowych są urządzenia oferowane przez firmę Nihon Kohden: 2-kanałowy MEB-9400 (rycina 3) oraz przeznaczony do zastosowań klinicznych i badawczych 6- lub 12-kanałowy MEB-2300K. Urządzenia posiadają odpowiednio 16- i 18-bitowe przetworniki analogowo-cyfrowe i pozwalają na rejestrację ABR, MLR, ECoG oraz na rejestrację słuchowych potencjałów wywołanych powolnym narastaniem szczytu (SVR). Opcjonalnie aparat można używać do badań śródoperacyjnych, wywoływania i rejestracji fali P300 i ujemnej fali oczekiwania CNV. System MEB-9400 dostępny jest w wersji stacjonarnej i przenośnej (walizkowej), a MEB-2300K wyłącznie w wersji stacjonarnej. Warto podkreślić, że w aparacie MEB-2300K zastosowano technologię aktywnej elektrody i ekranowanych przewodów, która służy do redukcji artefaktów.

Aparat Sierra Summit, który znajduje się w ofercie firmy Cadwell, pozwala na wykonywanie rejestracji potencjałów z 2 do nawet 12 kanałów. Przeznaczony jest do potencjałów elektromiografii - EMG oraz do rejestracji słuchowych potencjałów wywołanych: ECoG, ABR, MLR, LLR, P300 jak również wzrokowych i przedsionkowych potencjałów wywołanych i elektroretinografii. Urządzenie ma szereg funkcji pozwalających na dodatkową obróbkę zarejestrowanych odpowiedzi (np. sumowanie, odejmowanie, uśrednianie i odwracanie) i oferowane jest w wersji przenośnej oraz stacjonarnej.

\section{Systemy do rejestracji potencjałów korowych przeznaczone do prowadzenia badań naukowych}

Systemy przeznaczone do prowadzenia badań naukowych powinny cechować się możliwością wykonania rejestracji 
z wielu odprowadzeń (kanałów) oraz umożliwiać indywidualną obróbkę i analizę zarejestrowanych odpowiedzi. $\mathrm{W}$ badaniach naukowych bardzo istotne jest zarejestrowanie rzeczywistego sygnału EEG, który następnie poddawany jest dalszym obróbkom i w zależności od rodzaju zastosowanego pobudzenia uzyskuje się parametry poszczególnych grup potencjałów. Systemy naukowe posiadają możliwość eksportu zarejestrowanych odpowiedzi do innych programów (Matlab, Statistica), w których prowadzone są dalsze analizy.

Jednym z takich systemów jest 21-kanałowy system Neuron-Spectrum-4/EPM pozwalający na rejestrację czynności bioelektrycznej mózgu (EEG). Opcjonalnie system umożliwia rejestrację potencjałów wywołanych (SEP, VEP, AEP, P300 i CNV). Warto zwrócić uwagę na możliwość wykonywania badań oceniających funkcje językowe (N400 i P600).

Systemem rekomendowanym do prowadzenia badań naukowych i eksperymentalnych jest również urządzenie firmy Mitsar (rycina 4). Umożliwia ono wykonanie rejestracji czynności bioelektrycznej mózgu oraz wykonywanie ilościowej analizy sygnału EEG, czyli QEEG. Dedykowane oprogramowanie umożliwia przeprowadzenie obliczeń mocy sygnału, koherencji bispektralnych i bikoherencji, mapowanie parametrów spektralnych dla zakresów pasm, dokonywanie wyliczeń wartości współczynników pasm, wykreślanie map asymetrii oraz przeprowadzanie analizy składowych niezależnych (ang. independent component analysis, ICA) sygnału EEG. Do zalet tego systemu należy zaliczyć możliwość przeprowadzenia zaawansowanych korekcji artefaktów opartych na dekompozycji PCA i ICA surowego zapisu EEG oraz automatyczne wyszukiwanie artefaktów w celu usunięcia ich przed prowadzeniem dalszych analiz. Wraz z systemem oferowane jest oprogramowanie WINN EEG, które umożliwia dodatkowo wykonywanie i analizowanie zapisów potencjałów związanych ze zdarzeniem (ERP). Potencjały mogą być wywoływane zarówno za pomocą bodźców wzrokowych, jak i słuchowych na paradygmaty: TOVA (ang. Test of Variables of Atention), VCPT (ang. Visual Continuous Performance Tests) oraz za pomocą zadania matematycznego na trzech poziomach trudności, P300 i Go/Nogo. Istnieje również możliwość tworzenia własnych paradygmatów stymulacji wzrokowych i słuchowych. System pozwala na rejestrację i analizę potencjału niezgodności MMN oraz desynchronizację i synchronizację poszczególnych fal ERD (ang. event-relation desynchronization) i ERS (ang. event-relation synchronization) związanych ze zdarzeniem, obliczanie mocy falkowej (wavelet) wybranych pasm oraz koherencje odpowiedzi pomiędzy różnymi rejonami mózgu. Zaawansowana analiza rejestracji dzięki dedykowanemu oprogramowaniu pozwala na dokonanie mapowania poszczególnych parametrów odpowiedzi oraz porównanie otrzymanych wyników z bazą normatywną lub porównanie wyników uzyskanych u danej osoby przed terapią i po niej. Zintegrowana baza normatywna obejmuje trzyminutowe zapisy EEG dla oczu otwartych i zamkniętych oraz 5 zadań: Go/Nogo, MMN, zadanie matematyczne, czytanie i zadanie dźwiękowe. Dzięki temu możliwe jest wykonanie estymacji istotności różnic odpowiedzi ERP danego pacjenta z bazą normatywną z-score. Przewidziane jest eksportowanie surowych zapisów EEG w formacie EDF plus. Rejestrowanie i prezentację sygnału można przeprowadzać z wykorzystaniem wielu różnych montaży: jednobiegunowego, dwubiegunowego, $\mathrm{z}$ odniesieniem uśrednionym, odniesieniem ze średnią ważoną i in. System pozwala na filtrowanie zapisu EEG za pomocą filtrów IIR (ang. infinite impulse response) lub FIR (ang. finite impulse response filter). W zależności od zastosowanej głowicy sprzęt może mieć od 21 do 31 kanałów do rejestracji sygnału EEG oraz do 10 kanałów poligraficznych. Do badań diagnostycznych i naukowych polecane są głowice Mitsar EEG-202 AC lub Mitsar-202 DC, dysponujące 24 kanałami EEG i 8 kanałami poligraficznymi lub 31 kanałami EEG i jedną parą odprowadzeń aktywno-referencyjnych.

Urządzeniem przeznaczonym do badań naukowych jest także system GES 400 Series oferowany przez Electrical Geodesics (EGI), który w zależności od wersji i potrzeb użytkownika posiada 32, 64, 128 lub nawet 256 kanałów. Dodatkowo ma 2 standardowe kanały EKG i aż do 32 kanałów pomiarów fizjologicznych. Jego głównym zastosowaniem jest wykonywanie badań elektroencefalograficznych (EEG) oraz potencjałów związanych ze zdarzeniem ERP. Wyposażony jest w 24-bitowy procesor analogowo-cyfrowy o częstości próbkowania nawet do $20 \mathrm{kHz}$. Zintegrowany program Net Station pozwala na rejestrację i analizę danych EEG i ERP. Ponadto oprogramowanie do lokalizacji źródeł elektrycznych GeoSource pozwala na modelowanie źródeł mózgowej aktywności elektrycznej metodami inwersji, takimi jak LAURA, LORETA czy EPIFOCUS. System do fotogrametrii - A Geodesic Photogrametry - służy do precyzyjnego lokalizowania elektrod. Można tworzyć własne montaże i bazy danych pacjentów, wykonywać między innymi analizy czasowo-częstotliwościowe czy prezentować wyniki w postaci map topograficznych 2D i 3D. System pozwala na wykonywanie rejestracji w rezonansie magnetycznym MRI.

Ciekawym rozwiązaniem technologicznym jest przenośny aparat Eego sport, oferowany przez firmę Eemagine Medical Imaging Solutions $\mathrm{GmbH}$, umożliwiający nagrywanie czynności bioelektrycznej mózgu jednocześnie z 64 kanałów EEG i posiadający do 24 kanałów bipolarnych. Jego waga wynosi zaledwie 500 g, a wymiary urządzenia to: $160 / 205 / 22 \mathrm{~mm}$. System ten cechuje duża odporność na artefakty ruchowe i mięśniowe, co sprawia, że polecany jest do wykonywania badań EEG i EMG w różnych warunkach, w tym u pacjentów w ruchu (na przykład u sportowców) oraz pacjentów wykonujących określone zadania (uczenie się, prowadzenie samochodu, robienie zakupów itp.). Posiada 24-bitowy przetwornik analogowo-cyfrowy i 8-bitowy wyzwalacz.

Firma Eemagine Medical Imaging Solutions GmbH oferuje również zaawansowany system Eego mylab, posiadający 32, 64, 128 lub 256 kanałów EEG oraz 24 kanały bipolarne, w wersji stacjonarnej oraz mobilnej. Pozwala na prowadzenie rejestracji w połączeniu z TMS (ang. transcranial magnetic stimulation), MEG (ang. magneto-encephalography), fMRI (ang. functional magnetic resonance imaging).

W pracowniach naukowych znajduje zastosowanie również system SynAmps RT, produkowany przez firmę Compumedics Neuroscan. Urządzenie to ma 64 kanały jednobiegunowe, 4 dwubiegunowe i 2 wejścia na urządzenia zewnętrzne. Posiada także 24-bitowy przetwornik 
analogowo-cyfrowy, z częstością próbkowania $20 \mathrm{kHz}$ dla każdego kanału. Dedykowany jest do wykonywania badań: EEG, wzrokowych i słuchowych potencjałów wywołanych, a także fali P300, MMN i CNV. Współpracuje z zewnętrznym stymulatorem bodźców typu Presentation, co pozwala na stosowanie różnych bodźców, w tym sylab.

System MagLink (wzmacniacz SynAmps RT wraz z zestawem filtrów MagLink) umożliwia jednoczesną rejestrację EEG/ERP w rezonansie magnetycznym. Dedykowane oprogramowanie CURRY pozwala na wykonanie zaawansowanych analiz zapisów powierzchniowych, w tym identyfikacji iglic, uśredniania oraz analiz statystycznych. Oprogramowanie to tworzy mapy topograficzne 2D i 3D na podstawie obrazów indywidualnej anatomii uzyskanych z MRI. Do rejestracji używa się czepków Quik-Cap w 5 różnych rozmiarach.

\section{Podsumowanie}

Dystrybutorzy oraz producenci aparatów do rejestracji elektrofizjologicznych posiadają obecnie bogatą ofertę systemów i aparatów umożliwiających zarejestrowanie późnych potencjałów korowych. Wśród systemów tych są zarówno proste $\mathrm{w}$ obsłudze aparaty przeznaczone do zastosowań klinicznych, jak i zawansowane systemy do badań naukowych (nie tylko układu słuchowego). Do badań diagnostycznych, umożliwiających obserwację rejestrowanych potencjałów bezpośrednio w trakcie badania, zalecane są systemy jedno- i dwukanałowe. Oczekuje się, że wynik badania uzyskany na podstawie rejestracji z systemu diagnostycznego pozwoli na wykrycie nieprawidłowości występujących na wyższych piętrach drogi słuchowej, w celu podjęcia decyzji o ewentualnym rozszerzeniu diagnostyki o dalsze badania i konsultacje specjalistyczne. Natomiast systemy naukowe posiadają możliwość tworzenia wielu własnych schematów badawczych, parametryzacji ustawień rejestracji i stymulacji czy opcji pozwalających w różnych sposób zaprezentować wyniki złożonych analiz zarejestrowanego sygnału.
W pracowni diagnostycznej optymalne systemy, biorąc pod uwagę czas wykonania badania oraz łatwość obsługi, to: Chart EP 200 firmy Otometrics, Nicolet Viking EDX, którego dystrybucją zajmuje się Natus, oraz Neuro-Audio oferowany przez Neurosoft. Natomiast do badań naukowych najlepszymi rozwiązaniemi wydają się: aparat firmy Mitsar z oprogramowaniem WINN EEG, SynAmps RT produkowany przez firmę Compumedics Neuroscan lub urządzenie GES 400 Series oferowane przez Electrical Geodesics (EGI).

Pracownicy Instytutu Fizjologii i Patologii Słuchu mają do dyspozycji kilka systemów badawczych, które umożliwiają prowadzenie badań późnych odpowiedzi korowych. $\mathrm{Na}$ podstawie wykonanych rejestracji ERP u pacjentów z różnymi zaburzeniami audiologicznymi i foniatrycznymi oraz w grupach normatywnych przygotowano szereg publikacji, a wyniki badań były prezentowane na krajowych i międzynarodowych zjazdach i konferencjach naukowych.

Wyniki z badań wykorzystujących potencjały korowe zarejestrowane za pomocą systemu Chartr EP 200 zostały opisane w artykułach opublikowanych w „Otolaryngologii Polskiej” i „Standardach Medycznych” [21-23].

Wyniki rejestracji potencjałów korowych (egzogennych i endogennych) wykonane za pomocą 64-kanałowego systemu SynAmps RT zostały również opublikowane w czasopismach: „Magnetic Resonance Materials in Physics, Biology and Medicine”, „Medical Science Monitor” [24,25] oraz w „Otolaryngologii Polskiej” [26].

W chwili obecnej prowadzone są rejestracje potencjałów korowych związanych ze zdarzeniem $\mathrm{z}$ wykorzystaniem 19-kanałowego systemu Mitsar u pacjentów z chronicznym szumem usznym, z ośrodkowymi zaburzeniami słuchu oraz u osób z wszczepionym implantem ślimakowym.

Publikacja powstała $w$ zwiazku $z$ realizacja projektu pn. „Zintegrowany system narzędzi do diagnostyki i telerehabilitacji schorzeń narządów zmysłów (słuchu, wzroku, mowy, równowagi, smaku, powonienia)" INNOSENSE, współfinansowanego przez Narodowe Centrum Badań i Rozwoju w ramach Programu STRATEGMED.

\section{Piśmiennictwo:}

1. Milner R. Słuchowe potencjały korowe. Część I. Klasyfikacja oraz wybrane techniczne aspekty rejestracji odpowiedzi. Nowa Audiofonologia, 2015; 4(2): 17-27.

2. Senderski A. Potencjały związane ze zdarzeniem (ERP) - obiektywne narzędzie do oceny procesu rozumienia mowy. Audiofonologia, 2005; 27: 11-17.

3. Kochanek K. Słuchowe potencjały wywołane. W: Śliwińska-Kowalska M, red. Audiologia kliniczna. Łódź; 2005, s. 163.

4. McPherson D, Ballachanda B. Middle and long latency auditory evoked potentials. W: Roeser V, Dunn H, red. Audiology diagnosis. New York; 2000, 471-501.

5. Kutas M, Hillyard SA. Event-related brain potentials to grammatical errors and semantic anomalies. Mem Cognit, 1983; 11(5): 539-50.

6. Dong S, Reder LM, Yao Y, Liu Y, Chen F. Individual differences in working memory capacity are reflected in different ERP and EEG patterns to task difficulty. Brain Res, 2015; 1616: 146-56.
7. Muir WJ, Squire L, Blackwood DH, Speight MD, St Clair D, Oliver C i wsp. Auditory P300 response in the assessment of Alzheimer's disease in Down's syndrome: A 2-year follow-up study. J Ment Defic Res, 1988; 32: 455-63.

8. Tomé D, Sampaio M, Mendes-Ribeiro J, Barbosa F, Marques-Teixeira J. Auditory event-related potentials in children with benign epilepsy with centro-temporal spikes. Epilepsy Res, 2014; 108(10): 1945-49.

9. Weber-Fox C, Hampton Wray A, Arnold H. Early childhood stuttering and electrophysiological indices of language processing. J Fluency Disord, 2013; 38: 206-21.

10. Schaperle RA, Abbas PJ. Peripheral and central contributions to cortical responses in cochlear implant users. Ear Hear, 2015; w druku.

11. Kraus N, Micco AG, Koch DB, McGee T, Carrell T, Sharma A i wsp. The mismatch negativity cortical evoked potential elicited by speech in cochlear-implant users. Hear Res, 1993; 65(1-2): 118-24. 
12. Mahmoudian S, Farhadi M, Najafi-Koopaie M, Darestani-Farahani E, Mohebbi M, Denger R i wsp. Central auditory processing during chronić tinnitus as index by topographical maps of the mischmatch negativity obtained with the multifeature paradigm. Brain Res, 2013; 1527: 161-73.

13. Weber-Fox C, Leonard LB, Hampton Wray A, Tomblin JB. Elektrophysiological correlates of rapid auditory and linguistic processing in adolecents with specific language impairment. Brain Lang, 2010; 115(3): 162-81.

14. Stevens C, Sanders L, Neville H. Neurophysiological evidence for selective auditory attention deficits in children with specific language impairment. Brain Res, 2006; 1111(1): 143-52.

15. Roca P, Mulas F, Presentación-Herrero MJ, Ortiz-Sánchez $P$, Idiazábal-Alecha MA, Miranda-Casas A. Cognitive evoked potentials and executive functions in children with attention deficit hyperactivity disorder. Rev Neurol, 2012; 54(Suppl. 1): 95-103.

16. Roca P, Presentación-Herrero MJ, Miranda-Casas A, Mulas F, Ortiz-Sánchez P. The P300 component as a neurophysiological correlate of behavioural working memory in adolescents with attention deficit hyperactivity disorder. Rev Neurol, 2014; 58(Suppl. 1): 51-56.

17. Wiemes GR, Kozlowski L, Mocellin M, Hamerschmidt R, Schuch LH. Cognitive evoked potentials and central auditory processing in children with reading and writing disorders. Braz J Otorhinolaryngol, 2012; 78(3): 91-97.

18. Morlet D, Fischer C. MMN and novelty P3 in coma and other altered states of consciousness: a review. Brain Topogr, 2014; 27(4): 467-79.
19. Li R, Song WQ, Du JB, Huo S, Shan GX. Connecting the P300 to the diagnosis and prognosis of unconscious patients. Neural Regen Res, 2015; 10(3): 473-80.

20. Morand-Beaulieu S, O'Connor KP, Sauvé G, Blanchet PJ, Lavoie ME. Cognitive-behavioral therapy induces sensorimotor and specific electrocortical changes in chronic tic and Tourette's disorder. Neuropsychologia, 2015; pii: S0028-3932(15)30039-7.

21. Szkiełkowska A, Włodarczyk E, Senderski A, Skarżyński H, Ganc M, Piłka A. Ocena procesów przetwarzania słuchowego u dzieci z dyslalią. Otolaryngologia Polska, 2009; 63(1): 54-57.

22. Włodarczyk E, Szkiełkowska A, Senderski A. Ocena funkcji procesów centralnego przetwarzania słuchowego u dzieci z dyslalią. Standardy Medyczne Pediatria, 2011; 4(8): 100-9.

23. Włodarczyk E, Szkiełkowska A, Skarżyński H, Piłka A. Zaburzenia artykulacji u dzieci ze współistniejącymi zaburzeniami przetwarzania słuchowego - efekty terapii słuchowej. Otolaryngologia Polska, 2011; 65(5): 339-44.

24. Rusiniak M, Lewandowska M, Wolak T, Pluta A, Milner R, Ganc $\mathrm{M}$ i wsp. A modified oddball paradigm for investigating of neural correlates of attention - a simultaneous ERP-fMRI study. MAGMA, 2013; 26(6): 511-26.

25. Milner R, Rusiniak M, Lewandowska M, Wolak T, Ganc M, Piątkowska-Janko E i wsp. Towards neural correlates of auditory stimulus processing: a simultaneous auditory evoked potentials and functional magnetic resonance study using an odd-ball paradigm. Med Sci Monit, 2013; 20: 2256-68.

26. Milner R, Rusiniak M, Wolak T, Piątkowska-Janko E, Naumczyk P, Bogorodzki P. i wsp. Wykorzystanie jednoczesnych rejestracji słuchowych potencjałów korowych i funkcjonalnego rezonansu magnetycznego do badania procesów ośrodkowej części układu słuchowego - wyniki wstępne. Otolaryngologia Polska, 2011; 65(3): 171-83. 